\title{
Some Aspects of the Life-History Strategy of Pellonula Leonensis (Boulenger, 1916) (Teleostei: Clupeidae) in Qua Iboe Estuary, Nigeria
}

\author{
Aniefiokmkpong O. Okon ${ }^{1}$, Imaobong E. Ekpo ${ }^{2 *}$, Mmadara A. Okon ${ }^{3}$ and Anthony W. Akpan ${ }^{1}$ \\ ${ }^{\mathrm{T}}$ Department of Animal and Environmental Biology, Faculty of Science, University of Uyo, Uyo, Nigeria \\ ${ }^{2}$ Department of Fisheries and Aquatic Environmental Management, Faculty of Agriculture, University of Uyo, 520001, \\ Uyo, Akwa Ibom State, Nigeria \\ ${ }^{3}$ Department of Fisheries \& Aquaculture, University of Port Harcourt, Rivers State, Nigeria
}

\section{*Corresponding Author}

Imaobong E. Ekpo

\section{Article History}

Received: 11.06 .2020

Accepted: 19.06 .2020

Published: 08.07.2020

\begin{abstract}
Some aspects of the life-history strategy of the clupeid, Pellonula leonensis in Qua Iboe estuary, Nigeria were investigated. Results obtained showed that length-weight relationship was approximately isometric (exponent, $b=$ 3.010 ), estimated asymptotic total length, $\mathrm{L}_{\infty}=11.5 \mathrm{~cm}$ and growth coefficient, $\mathrm{K}=1.5 \mathrm{yr}^{-1}$; these parameters were used to derive the Von Bertalanffy's length models; $\mathrm{L}_{\mathrm{T}}=11.5\left(\mathrm{I}-\mathrm{e}^{1.5 \mathrm{~T}}\right)$, the coefficient total mortality, $\mathrm{Z}=8.22 \mathrm{yr}^{-1}$, natural mortality, $\mathrm{M}=3.12 \mathrm{yr}^{-1}$ and fishing mortality, $\mathrm{F}=5.10 \mathrm{yr}^{-1}$. The exploitation ratio $(\mathrm{E}=0.62)$ indicated that this stock of P. leonensis was being overexploited at $12 \%$ above its optimum yield level. A protraction of the ongoing exploitation rate could endanger and lead to the collapse of the fishery. Breeding was year-round with minimum and maximum intensities in May and December respectively. Absolute fecundity was 2,286 - 4,509 eggs (Mean eggs = 3,133). The fish was recruited into the artisanal fishery at size $3.0 \mathrm{~cm}$ before attaining sexual maturity. This is an undesirable situation since there is a high risk of depleting the stock of potential spawners. The main life-history traits of P. leonensis (rapid growth, early sexual maturity, high fecundity, year-round breeding, small maximum body size, and high natural mortality) were typical of an $\gamma$-selected species. However, P. leonensis exhibited iteroparity rather than semelparity.
\end{abstract}

Keywords: growth parameters, reproductive attributes, r-selection, Pellonula leonensis, Qua Iboe estuary, Nigeria.

\section{INTRODUCTION}

The Atlantic coastal waters of the Gulf of Guinea, from Senegal to Zaire, support a considerable stock of the shoaling pelagic-clupeid, $P$. leonensis. This species and other clupeids are of high commercial importance in the Nigeria inshore waters (Otobo [1]; Ikomi [2]; Kunzel et al. [3]; Ita [4]; Akpan et al. [5] where they constitute important catch component of artisanal fisher folks in Qua Iboe estuary, East of the Niger Delta. The artisanal fishery is sustained by $P$. leonensis among other clupeids. Considering the economic importance of this fishery in terms of providing employment and rich protein source for several Nigerians living in the hinterland and riparian communities, particularly the less privileged people who constitute the majority in the tropical countries and also affordable source of bait and ingredient for livestock feed manufacturing, it is surprising that only few workers have studied aspects of the biology of $P$. leonensis.

Most of these investigations have concentrated on the populations of P. leonensis in Epe Lagoon in Lagos (Balogun, [6], in Lake Kainji [Otobor, [1]; Otobo \& Imevbore, [7]] in upper Niger and lower Benue [Ikomi, 2]. Comparatively, little is known about the biology of this species elsewhere. A notable exception is the works of Moses [8] and Kunzel \& Lowenberg [9] who reported the ecology and fisheries in Cross River, Nigeria and population dynamics of Pellonula leonensis in Cross River respectively. No attempt has hitherto been made to assess the life-history strategy of $P$. leonensis, the knowledge of which is of prime value in the formulation of rational stock management and conservation policies for this species.

Copyright @ 2020: This is an open-access article distributed under the terms of the Creative Commons Attribution license which permits unrestricted use, distribution, and reproduction in any medium for non commercial use (NonCommercial, or CC-BY-NC) provided the original author and source are credited. 
The present study contributes to the biology of $P$. leonensis by providing data on the life-history characteristics of the population in the Qua Iboe estuary, Nigeria which has in last three decades been subjected to heavy anthropogenic environmental stresses arising from crude oil pollution [Umoren \& Onianwan, [10]; Andem et al. [11]] and other petroleum exploitation-related perturbations. The life-history strategy of an organisms involves a combination of a number of traits including size and age at first capture, longevity (maximum age attainable), maximum body size attained, mortality, and/or survival rates, reproductive effort and responses to environmental variability (Bone \& Marshall, [12]). The interplay of these attributes determines the fitness of the organism to growth, reproductive success, survival and the maintenance of several forms of interactions with its biotic and abiotic environments. In this paper, particular attention is given to growth, mortality and reproductive attribute of $P$. leonensis using an integrative approach. The results are elucidated by being discussed in the context of the evolution of K- and r-selection strategies (MacArthur \& Wilson, [13]).

\section{Materials ANd Methods}

Qua Iboe estuary (Fig. 1) is in Akwa Ibom State, Nigeria lies in the area East of the Niger Delta between Cross River and Imo River estuaries, (longitude $7^{\circ} 30-8^{\circ} 20 \mathrm{E}$; latitude $4^{\circ} 30-5^{\circ} 30 \mathrm{~N}$ ). Besides the wide opening into the Gulf of Guinea at the Bight of Bonny, this estuarine ecosystem includes mixohaline water, tidal, creeks, small lagoons and fringing mangrove swamps. The macrophytes of the mangrove swamps are dominated by Rhizophora harrizonii, Leechman, Rhizophora mangle I., Rhizophora racemosa Mey (red mangroves: Rhizophoraceae), Avicennia africana Beauv (white mangrove: Avicenniaeae) and Laguncularia racemosa Gaetm (black mangrove: Combretaceae) (Ekpo et al. [14]). Others include the pteridophytes, Acrosteichum aureum L. (Adiantaceae) and the palms, Nypa fruticans Wurmb and Phoenix reclimate Jacq (Palmae). The bottom of the estuary consists mainly of silt, mud and considerable accumulation of organic detritus transported downstream by the river. The depth of the main estuary is $0.5-9.0 \mathrm{~m}$ while the tidal amplitude is $1-3 \mathrm{~m}$.

Qua Iboe estuary is located in the equatorial rainforest climatic belt of southern Nigeria typified by year-round precipitation. Inspite of this, two major seasons are discerned in the area; the dry season extends from November to March with peak in January while the rainy season ranges between April and October with peak in July. Further details regarding the Qua Iboe River basin $\left(7^{\circ} 30-8^{\circ} 20 ; 4^{\circ} 30-5^{\circ} 30 N\right)$ are contained in Tahal Consultants Ltd [15].

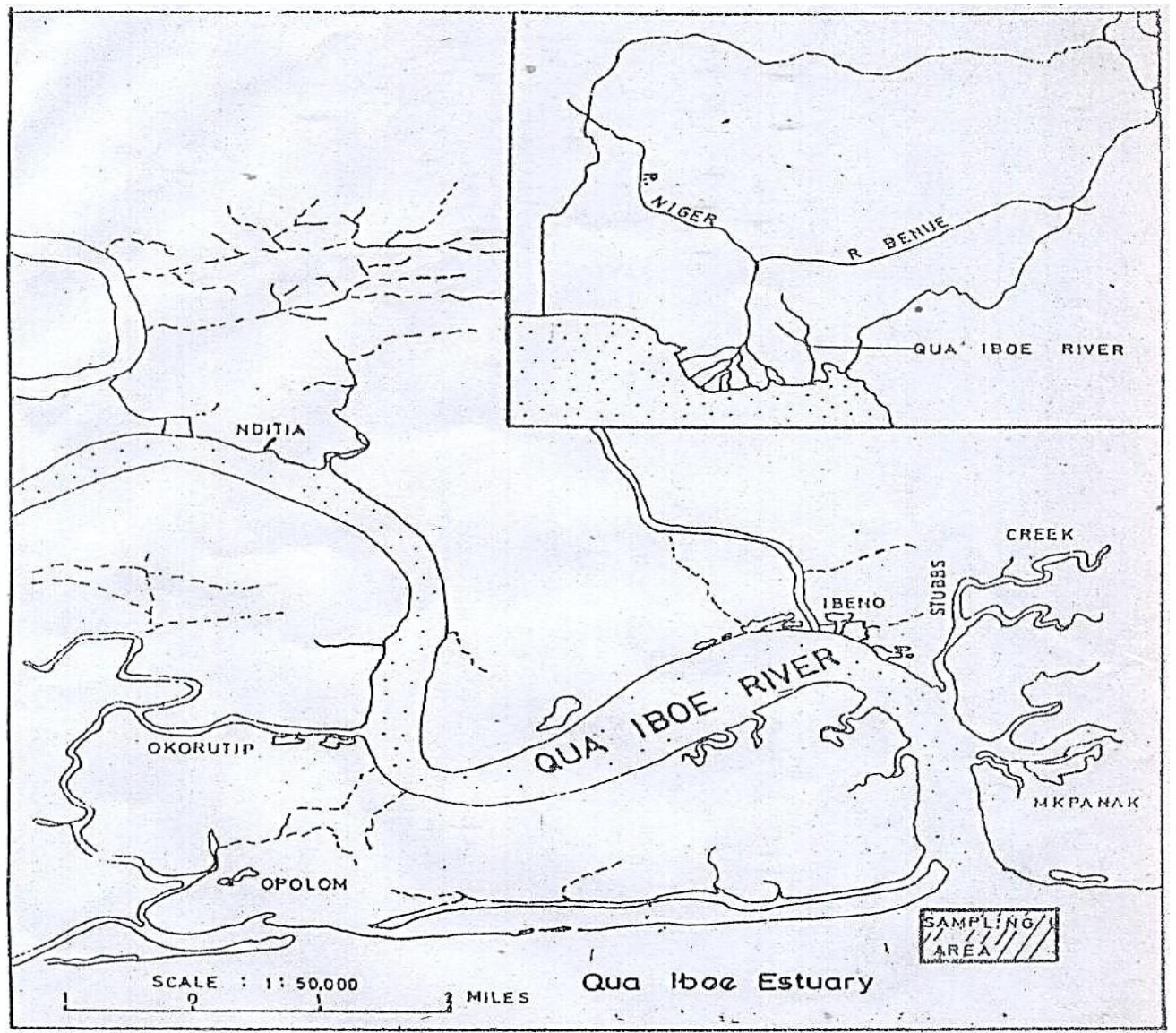

Fig-1: Map of Qua Iboe River estuary showing the sampling station. (Insert: Map of Nigeria showing the location of Qua Iboe River) 
From January - December 2010, a total of 1,747 random specimens of $P$. leonensis were obtained from artisanal fishers at Ibeno fishing harbour. Fishing was by the use of lift nets called traditionally as "atalla" measuring $2.9 \times 2.9 \mathrm{~m}$, mesh size $1 \mathrm{~mm}$. Specimens were measured to the nearest $0.1 \mathrm{~cm}$ total length and weighed to the nearest $0.1 \mathrm{~g}$ total weight after draining water from the buccal cavity. The fish were divided into $1.0 \mathrm{~cm}$ length categories and the FAO/ICLARM Stock Assessment Tools (FiSAT) software was used to determine the growth and mortality parameters of the fish (Pauly, [16], [17]). The length growth performance index $\left(\emptyset^{1}\right)$ was estimated from the parameters of the Von Bertallanffy's Growth Model (VBGM) (Pauly and Munro, [18]).

Thus,

$$
\emptyset^{1}=\log \mathrm{K}+2 \log \mathrm{L}_{\infty}
$$

A total of 664 specimens of $P$. leonensis were obtained for studies of other reproductive attributes over a 1-year period. They were measured and weighed and sexed by visual inspection of the gonads after dissection. The ovaries of each specimen were weighed to the nearest $0.01 \mathrm{~g}$ and gonadosomatic index (GSI) calculated thus:

$$
\text { GSI }=\frac{\text { Ovary Weight }}{\text { Somatic weight }} \times 100
$$

The somatic weight $(\mathrm{g})$ of each fish specimen was calculated as the difference between fish total weighted gonad weights (ovary weight). Ovarian stages of maturity were categorised as immature, mature, ripe and spent stages following criteria given by Lagler et al. [19]. To estimate absolute fecundity (AF), ripe ovaries from each of 60 selected females were preserves in labeled vials containing $4 \%$ formaldehyde solution until the eggs hardened (over $2-4$ weeks). The vials were periodically agitated to ensure the separation of eggs from ovarian tissue. The eggs were later air-dried on absorbent paper for 24 hours at $27-30{ }^{\circ} \mathrm{C}$ ambient temperature. Absolute fecundity was then estimated gravimetrically following the methodology outlined in Wilkinson \& Jones [20].

The relationship between fecundity and each of the independent variables $\left(\mathrm{X}_{\mathrm{i}}\right)(\mathrm{e} . \mathrm{g}$. total length $(\mathrm{L})$, total weight (W), gonadosomatic index (GSI) and condition index (CI).

$$
\mathrm{CI}=\frac{\text { Somatic Weight }}{\mathrm{TL}^{3}} \times 100
$$

Was represented by the exponential functions:

$$
\text { Fecundity }=\mathrm{aX}_{\mathrm{i}}^{\mathrm{b}}
$$

Where,

$\mathrm{a}=\mathrm{a}$ constant and $\mathrm{b}=$ regression coefficient; both of which are estimated by least squares linear regression analysis using Log/log transformed data.

\section{RESUlts}

\section{Size Composition}

Total length and weight of $P$. leonensis were significantly correlated $(\mathrm{r}=0.9 ; 421 ; \mathrm{df}=\mathrm{P}<0.05)$ for combined sexes of fish measuring $3.0-10.0 \mathrm{~cm}$ and weighing $0.52-9.0 \mathrm{~g}$. An exponential expression of the form, TW $=0.6013$ $\mathrm{TL}^{3.010}$ accounted for $96.4 \%$ of the variation in fish total weight (Fig. 2). 


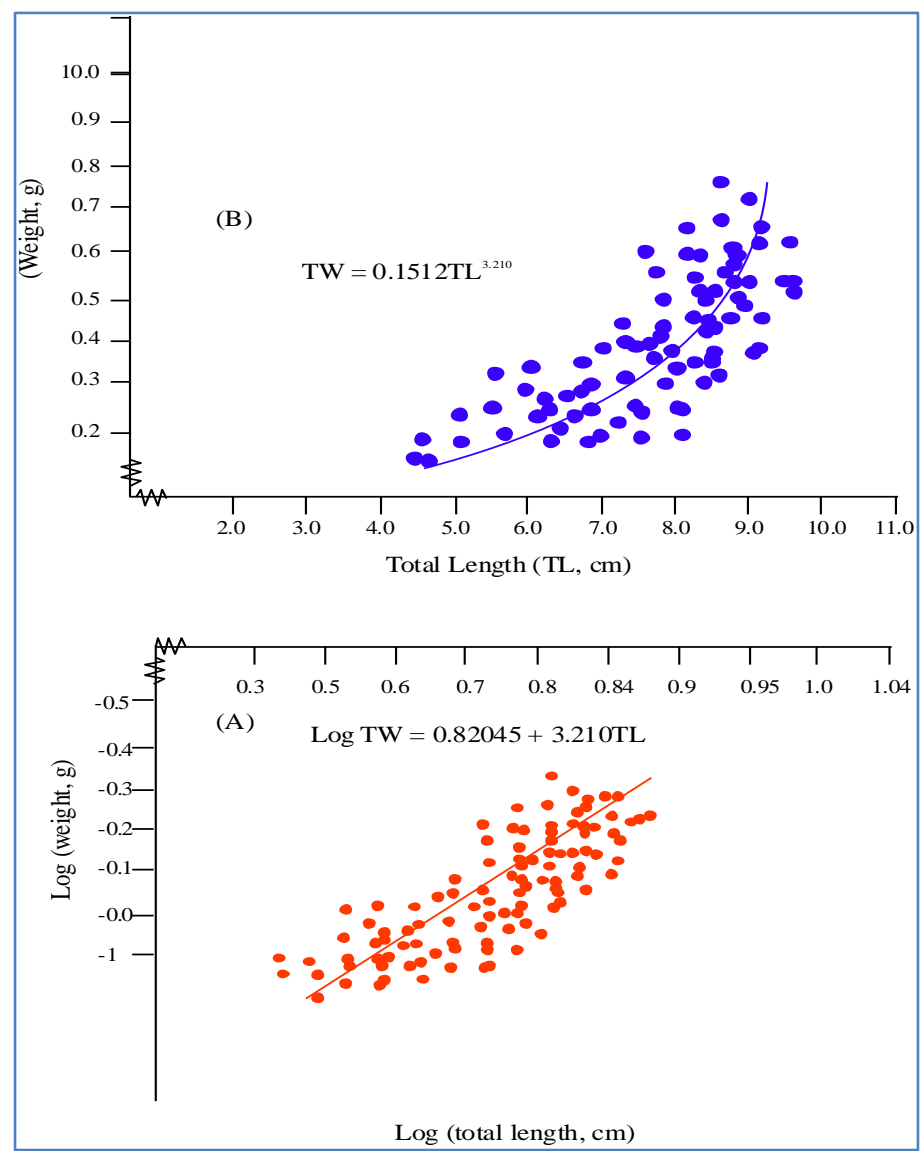

Fig-2: Length - weight relationship of P. leonensis from Qua Iboe estuary, Nigeria (A = Log transformation; B = Linear transformation)

\section{Growth Pattern}

The monthly length frequency data of the specimens collected during this investigation are given in Table 1 . The growth parameters obtained were: $\mathrm{L}_{\infty}=11.5 \mathrm{~cm}$ and $\mathrm{Z} / \mathrm{K}=5.48$. The growth coefficient, $\mathrm{K}$ was $1.5 \mathrm{yr}^{-1}$. The Von Bertallanffy's growth resulting from the above growth parameters is represented as:

$$
\mathrm{LT}=11.5\left(\mathrm{I}-\mathrm{e}^{-1.5 \mathrm{~T}}\right)
$$

The length growth performance index, $\varnothing^{1}=2.32$.

Table-1: Length frequency data of Pellonula leonensis sampled in Qua Iboe Estuary (Nigeria) from January to December, 2004. (ML = Mid-length of class interval $(\mathrm{cm}), \mathrm{N}=3,817)$

\begin{tabular}{|c|c|c|c|c|c|c|c|c|c|c|c|c|}
\hline ML/DATE & $01 / 10$ & $02 / 10$ & $03 / 10$ & $04 / 10$ & $05 / 10$ & $06 / 10$ & ${ }^{07} / 10$ & $08 / 10$ & ${ }^{09} / 10$ & $10 / 10$ & $11 / 10$ & $12 / 10$ \\
\hline 2.0 & & & & & & & 1 & & & & & \\
\hline 2.5 & 13 & 1 & & & & & 0 & & & & & \\
\hline 3.0 & 60 & 17 & & 1 & & 1 & 1 & 1 & & & 2 & \\
\hline 3.5 & 12 & 8 & 1 & 0 & & 1 & 0 & 0 & & & 0 & \\
\hline 4.0 & 44 & 45 & 4 & 8 & 5 & 91 & 5 & 2 & 39 & 15 & 8 & 1 \\
\hline 4.5 & 4 & 81 & 37 & 24 & 51 & 6 & 0 & 2 & 11 & 4 & 10 & 0 \\
\hline 5.0 & 17 & 22 & 192 & 122 & 150 & 102 & 62 & 112 & 146 & 65 & 134 & 1 \\
\hline 5.5 & 0 & 23 & 104 & 124 & 26 & 22 & 23 & 38 & 18 & 20 & 29 & 2 \\
\hline 6.0 & 47 & 11 & 25 & 39 & 124 & 103 & 150 & 86 & 70 & 93 & 78 & 130 \\
\hline 6.5 & 45 & 17 & 14 & 19 & 2 & 8 & 1 & 2 & 2 & 2 & 5 & 23 \\
\hline 7.0 & 54 & 15 & 22 & 14 & 12 & 22 & 22 & 33 & 10 & 19 & 24 & 77 \\
\hline 7.5 & 51 & 4 & 10 & 11 & & 1 & 1 & 0 & 0 & 1 & 3 & 2 \\
\hline 8.0 & 14 & 2 & 9 & 3 & & 8 & 6 & 13 & 6 & 4 & 14 & 13 \\
\hline 8.5 & 3 & & 3 & & & 1 & 0 & 1 & 0 & & 1 & 0 \\
\hline 9.0 & & & & & & 2 & 2 & 9 & 2 & & 3 & 1 \\
\hline 9.5 & & & & & & 1 & 0 & 4 & & & & \\
\hline 10.0 & & & & & & 0 & 1 & 0 & & & & \\
\hline 10.5 & & & & & & 1 & & 1 & & & & \\
\hline & 364 & 246 & 421 & 376 & 370 & 369 & 277 & 304 & 308 & 223 & 309 & 250 \\
\hline
\end{tabular}




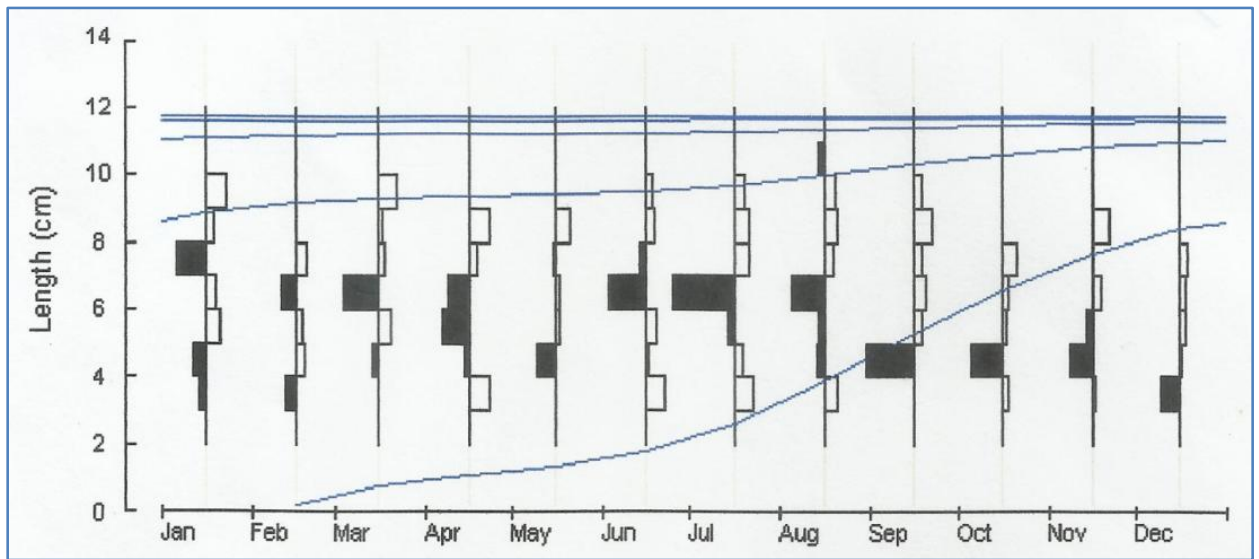

Fig-3: Plot of seasonalised Von Bertalanffy growth curves for $P$. leonensis $\left(L_{\infty}=11.5 \mathrm{~cm}, \mathrm{~K} \quad=1.5 \mathrm{yr}^{-1} \mathrm{C}=0.85, \mathrm{WP}=0.3\right)$ superimposed on the restructure length-frequency histograms in Qua Iboe estuary, Nigeria

\section{Mortality}

The seasonalised catch curve (Fig. 4) gave the estimated coefficient of total mortality, $\mathrm{Z}=8.22 \mathrm{yr}^{-1}$ and natural mortality $\mathrm{M}=3.12 \mathrm{yr}^{-1}$. Fishing mortality, $\mathrm{F}(\mathrm{F}=\mathrm{Z}-\mathrm{M})$ was $5.10 \mathrm{yr}^{-1}$. The computed exploitation rate, $\mathrm{E}(=\mathrm{F} / \mathrm{Z})$ gave 0.62 . The smallest size of $P$. leonensis under exploitation measured $3.0 \mathrm{~cm}$. The ratio of natural mortality to growth $\mathrm{M} / \mathrm{K}=$ 2.08 and that of fishing mortality to natural mortality, ${ }^{\mathrm{F}} / \mathrm{M}=1.63$. From the analysis of probability of capture of each length class (Fig-5), Lc was $5.55 \mathrm{~cm}$. The Selective $\mathrm{O}_{\text {give }}$ procedure was used to compute the relative yield-per-recruit (Fig. 6). The following results were obtained: $\mathrm{E}_{\max }=0.42, \mathrm{E}_{10}=0.36$ and $\mathrm{E}_{50}=0.28$.

The pooled 664 adult specimens sexed comprised 270 males and 394 females, which gave an overall male: Female ratio of 1.0: 1.5 ; portraying a strong female bias goodness of fit. $\left(\mathrm{X}^{2}=0.65 ; \mathrm{df}=1 ; \mathrm{P}<0.010\right)$.

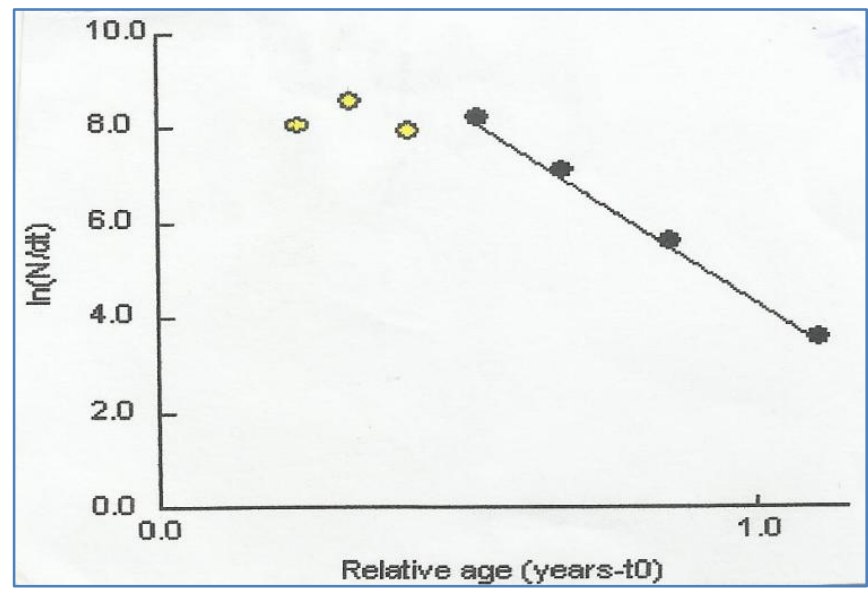

Fig-4: Seasonalized length-converted catch curve for P. leonensis from Qua Iboe estuary, Nigeria

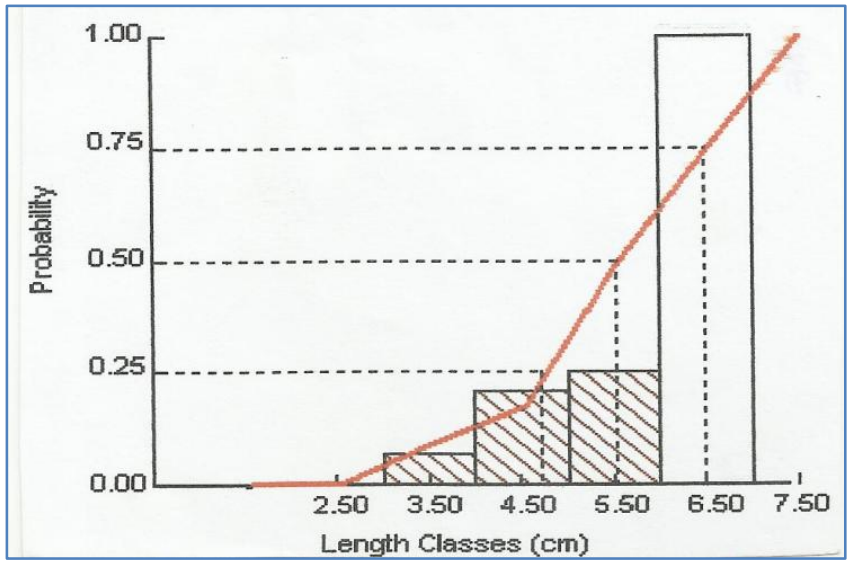

Fig. 5: Probability of capture of each size class of $P$. leonensis (The estimated length at first capture $L_{50}$ or $L_{c}=5.55 \mathrm{~cm} ; L_{25}=4.73 \mathrm{~cm}$ and $L_{75}=$ $6.49 \mathrm{~cm}$ ) in Qua Iboe estuary, Nigeria 


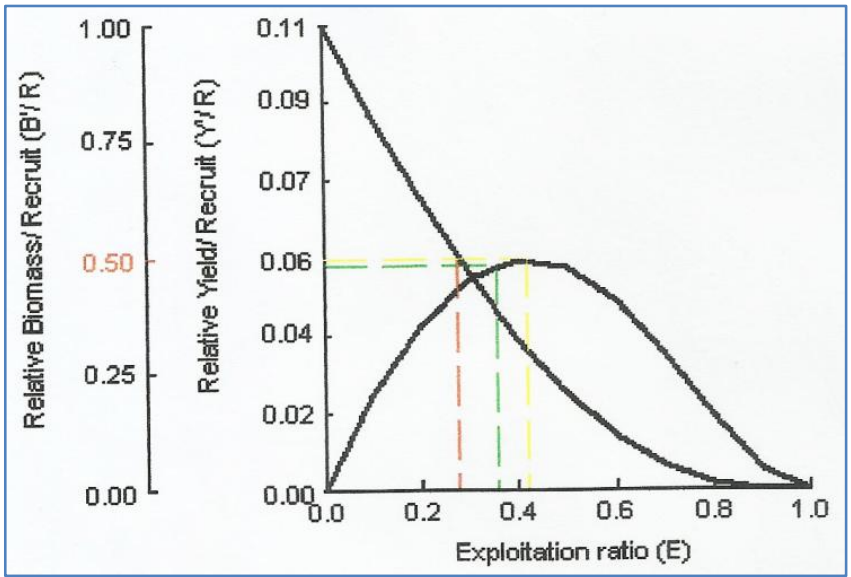

Fig-6: Relative yield per-recruit and relative biomass per-recruit using the selective $O_{\text {give }}$ procedure $\left(E_{\max }=0.42 ; E_{10}=0.36 ; E_{50}=0.28\right)$ in $Q u a$ Iboe estuary, Nigeria

\section{Reproductive Investment}

The changing pattern of reproductive investment (the fraction of body weight devoted to reproductive tissue i.e. GSI of $P$. leonensis with ovarian morphogenesis. Reproductive investment increased with ovarian maturation, peaking at the ripe stage and declining in spent fish. The relationship between gonadosomatic index and fish size in showed a decline in reproductive effort with increasing fish size.

\section{Breeding Seasonality}

Temporal regimes in occurrence of the gonadosomatic index for both sexes were depicted in Fig. 7. Ripe females were encountered all year-round in proportions varying from $42 \%$ in March to $66.7 \%$ in October. The occurrence of mature and ripe females in all months indicates a year-round breeding activity albeit in a pattern suggesting some seasonality. Monthly regimes in gonadosomatic index designated high breeding activity in August - September, January, June - July. The major breeding peak occurred in August (peak rainy season) and minor ones in June (early rainy season) and November (early dry season).
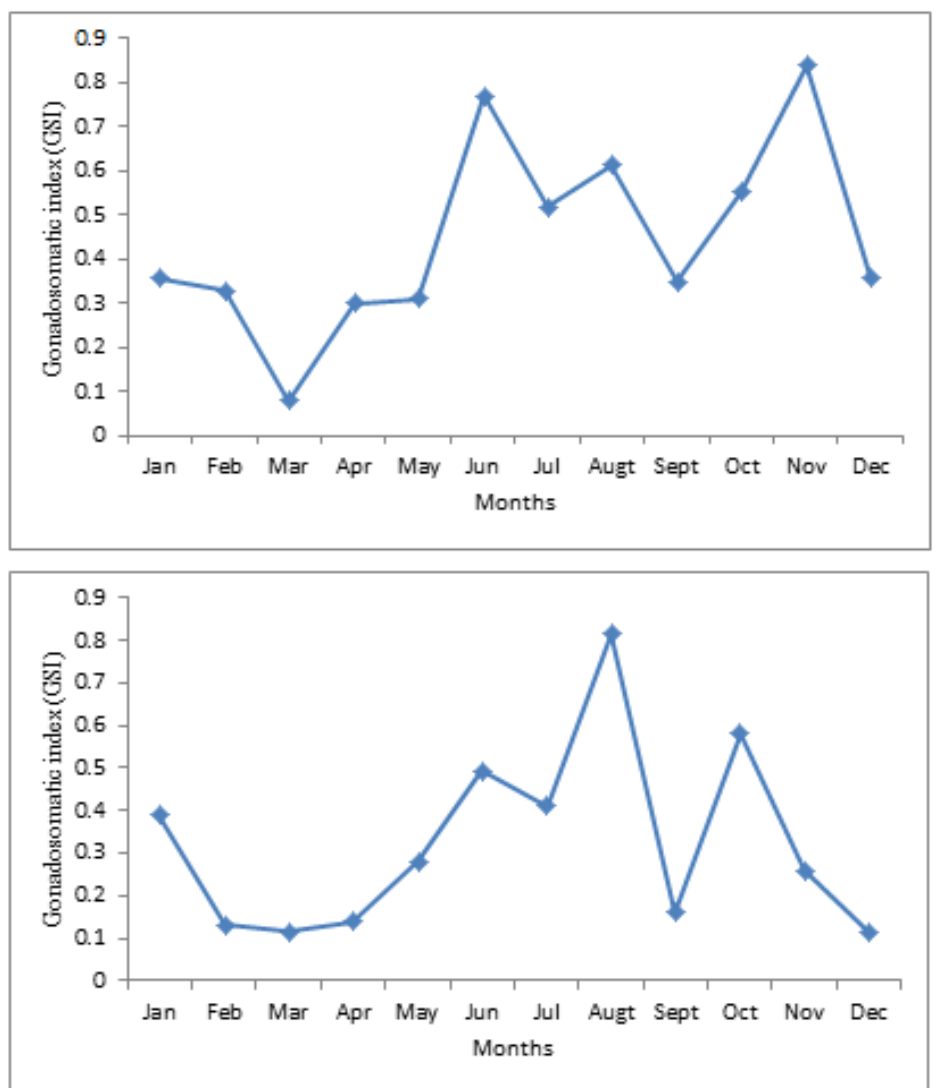

Fig. 7: Monthly trend in occurrence of the gonadosomatic indices for both sexes (A - Male and B - Female) of P. leonensis from Qua Iboe estuary, Nigeria 


\section{Fecundity}

Mean absolute fecundity estimate was 3,133 eggs (range 2,286 - 4,509) for fish of $6.5-9.5 \mathrm{~cm}$. It increased with fish size $(\mathrm{r}=0.0232$; df $58 ; \mathrm{P}<0.001)$ according to the expression, $\mathrm{AF}=2.448$; $\mathrm{TL}^{3.201}$ which accounted for 70 of the variance in egg number. Absolute fecundity also increased with fish total weight $(4.5-9.0 \mathrm{~g})$ according to the exponential equation of the form:

$\mathrm{AF}=2.431, \mathrm{TW}^{1.212}$

About $35.5 \%$ of the variation in absolute fecundity was explained by changes in fish total weight. Mean gonadosomatic index was 0.37 (range $0.11-0.71$ ), it increased with absolute fecundity $(r=0.613 ; \mathrm{P}<0.05)$. Changes in gonadosomatic index accounted for $60.4 \%$ of the variation in Absolute fecundity. The exponential expression for this relationship was:

$\mathrm{AF}=0.531 \mathrm{GSI}^{2.312}$

Condition index ranged between 0.05 and 1.66. Absolute fecundity and condition index were inversely correlated $(\mathrm{r}=-$ $0.451 ; \mathrm{P}<0.05)$; this was represented by the exponential function;

$\mathrm{AF}=0.713 \mathrm{CI}^{3.101}$

This accounted for $18.2 \%$ of the variation in total egg number. There was no significant relationship between absolute fecundity and condition index.

\section{DISCUSSION}

The length exponent in the length-weight relationship of pooled sexes of P. leonensis was 3, thus indicating that increase in weight is isometric. This is comparable with the findings of Akpan et al. [5]. For most fishes the length exponent lies between 2.5 and 4.0 (Lagler et al. [19]. The estimated asymptotic length seems reasonable in view of the maximum size encountered by the author in the estuary, $\mathrm{L}_{\max } 11.5 \mathrm{~cm}$ TL; compared with by other authors such as Balogun [6] in Ekpe Lagoon (Nigeria) $\mathrm{L}_{\max }=12.2 \mathrm{~cm}$ TL; and Lowenberg \& Kunzel [21] in Cross River (Nigeria) $\mathrm{L}_{\max }=$ $15.6 \mathrm{~cm}$.

The length growth performance index $\left(\emptyset^{1}\right)$ obtained here (2.32) corresponds fairly well with estimates for the stocks of allied clupeids e.g. Ethmalosa fimbriata $\left(\varnothing^{1}=2.59\right.$; Moses, [22]; Sardinella maderensis $\left(\varnothing^{1} 2.75\right.$; Djama et al. [23]); in inshore waters of West Africa. This corroborates the concept that values of the growth performance index of closely related taxa are very similar with minimum variance and can be used to characteristic members of the same family [Pauly \& Munro, [18]; Sparre et al. [24].

The exploitation ratio provides a rough estimate of whether or not a fish stock is over exploited based on the assumption that optimal yield level is attained when $\mathrm{E}=0.5$ (i.e. fishing mortality is about equal to natural mortality) [Gulland, 25]. The present finding indicates that human exploitation is instrumental to $62 \%$ of the total mortality of the stock of $P$. leonensis in Qua Iboe estuary and this exceeds its optimum yield level by $12 \%$. This will be deleterious to the persistence of the fishery since a protraction of the ongoing exploitation pressure could culminate in the collapse of the fish population and consequently, the fishery. The high $\mathrm{F} / \mathrm{M}$ ratio (1.63) for P. leonensis is an index typical of a heavily exploited fish stock and it confirms the author's earlier assertion that fishing mortality was the dominant element in total mortality.

The present finding which shows a strongly female - biased sex ratio of $P$. leonensis is similar to that of Ikomi [2] in River Warri; Ikusemiju et al. [26] in Lagos Lagoon, Nigeria; Marcus \& Ikusemiju [27] among clupeids in Lagos coast and Stockholm \& Isebor [28] in area of Benin Republic and off Lagos State, Nigeria. The above situation adds credence to the assertion by Roff [29] which holds that females continually replace themselves and fits the basic framework of life time; of average one female that herself survives to reproduce in order to maintain an equilibrium population. Moreso, the female dominance in number could be attributed to the fact that females are more active than males, thus are more vulnerable to capture - a behaviour that could be likened to the cichlids (Keansleyside, [30]).

This study revealed that $P$. leonensis bred on a year-round basis with high intensities in July - September, October - January. Breeding peaks occurred in January, August, September, October, November and December. Kunzel \& Lowenberg [9] recorded a similar year-round breeding in this species with peaks in January, February and a minor spawning peak in the early rainy season in Cross River. Ita [4] also affirms the early flood season as the species breeding season in Cross River. Moses [8] report reveals that the main spawning pulse also occurs from November. However, Kapetzky [31] reports that the most species in Magdalena River in Columbia (tropical South America) bred during February - April low waters and in the first stages of the rising flood. He also observed another peak breeding activity 
during the second stages of rising water in October while few species bred during falling water (December - January). The results from this work suggest a similar pattern.

Based on the afore findings of the present study, P. leonensis can be regarded as a multivoltine species, although further studies are needed to ascertain the number of generations of progeny that are produced annually by an individual fish. The species also appears to be a pelagic open-water spawner which merely broadcast eggs in the water and accords no parental care to the eggs or progeny.

The mean absolute fecundity of $P$. leonensis from Qua Iboe estuary is relatively lower compared to the value mean 2,859 eggs; range 140 - 4,9000 eggs) (Otobo \& Imevbore, [7]) for the population in Kainji Lake, Nigeria. This disparity could be attributed to a number of factors including availability of food resources, sizes and age of specimens examined, season and specific environmental conditions [King, 32].

Weasel et al. [33] noted the disparity in fecundity among populations of a given fish species as adaption to different environmental conditions that produce higher or lower survival opportunities for the species. This undoubtedly explains the lower fecundity of the species in this study area which is under intense eco-succession, deforestation, siltation and other human perturbations (Umoren \& Onianwan, [10]; Andem et al. [11]).

The life-histories of organisms can be expressed in terms of the theory of k- and $\gamma$-selection pressures operating in varying environments (MacArthor \& Wilson, [13]). This stipulates that k-selected species inhabit stable, crowded environments while r-selected species are fitted for high population growth rate in uncrowded but highly variable environments. Notwithstanding the criticisms, that the dichotomy is not perfect, too rigid and simplistic; and that it only represents the extremes of a continuum of methods for maximizing reproductive success (McNaughton \& Wolf, [34]). It is worth indicating that the notion of a continuum implies the existence of organisms that will exhibit both $\mathrm{k}$ - and $\gamma$ selected properties in their life-histories due to overlaps or their transitional positions along the continuum. This is expected, if the k- and $\gamma$-selected strategies are considered as non-rigid evolutionary trends toward the maximization of reproductive success. Thus, for a fish like Gasterosteus aculeatus L., which incorporates both the k- and $\gamma$-selected properties in its life history (O'Hara \& Penczak, [35]), it would be most appropriate to interpret it as occupying an intermediate position in the continuum of life-history strategies rather than inadequacy in the k- and $\gamma$-selection theory in describing the life-history adaption.

The k- and $\gamma$-selected theory has subsequently been expanded and made more flexible by incorporating other life-history attributes. Studies (Bone \& Marshall, [12] and O'Hara \& Penczak, [35]) have revealed $\gamma$-selection as favouring slow growth, low fecundity, large body size, delayed sexual maturity, and long life-span while $\gamma$-selection favours rapid growth, early sexual maturity, high fecundity, small body size and short life span.

\section{Conclusion}

Based on the aforementioned attributes, Pellonula leonensis of the Qua Iboe estuary, with a rapid exponential growth rate, high reproductive output (i.e. fecundity), small body size, high natural mortality and early sexual maturity can be classed as an $\gamma$-selected species. However, unlike a typical $\gamma$-selected species, P. leonensis exhibits iteroparity rather than semelparity. It is undoubtable that the latter life-history strategy could compensate for the rather high observed mortalities although the sustenance cannot be ascertained especially with the observed influences of stochastic environmental factors prevailing in the estuary.

\section{Acknowledgments}

We indebted to Mrs. Mary Sunday and Mr. Akaninyene Effiong for assistance in the field; Dr. Francis Nwosu for providing the software and analyzing the data; Mr. Samuel Etefia and Mrs. Sophia Ntuk for typing the work.

\section{REFERENCES}

1. Otobo, F. O. (1979). The fish fauna changes and the place of clupeids in Lake Kainji, Nigeria. Hydrobiologia, 64(2), 99-103.

2. Ikomi, R. B. (1993). Studies on the ecology of the clupeids: Pellonula leonensis (Reagain 1917) in River Warri (Niger Delta) Nigeria. Acta Hydrobiol., 135(4), 381-398.

3. Kunzel, T., Lowenberg, U., Ita, O. E., Ekpenyong, E., Enin, U. I., Mah-Essiet, E. N., \& Udo, P. J. (1985). Investigation on Pellonula sp along the Cross River. Kainji Lake Research Institute. Ann. Rep., 5-57.

4. Ita, E. O. (1983). Fish transplantation studies: Preliminary investigations on the distribution and abundance of different length groups of the clupeid fish Pellonula afzeliusi in the Cross River. Kainji Lake Research Institute Annual Report, 110-114. 
5. Akpan, B. E., Akpan, A. W., Udo, M. T., \& Akpabio, E. E. (2005). Food and feeding performance of Pellonula leonensis (Reagan, 1917) (Clupeidae) from Cross River estuary, Nigeria. Applied Zoology and Environmental Biology, 7, 131-135.

6. Balogun, J. K. (1987). Studies on some aspects of the biology of Pellonula afzeliusi in Epe Lagoon, Nigeria. Arch. Hydrobiol., 109, 517-523.

7. Otobo, F. O., \& Imevbore, A. M. A. (1979). The development of a clupeid fishery in Nigeria. In: Proceedings of the International conference on Kainji Lake and River Basins Development in Africa, Ibadan, 11 - 17 December, 288 295.

8. Moses, B. S. (1979). The Cross River; its ecology and fisheries. In Proceedings of the International Conference on Kainji Lake and river basin development in Africa (pp. 365-367).

9. Kuenzel, T., \& Loewenberg, U. (1990). Studies on the population dynamics of Pellonula leonensis (Clupeidae) in the Cross River, Nigeria. Fishbyte, 8(1), 8-12.

10. Umoren, I. U., \& Onianwa, P. C. (2012). Surface water quality status and chemical speciation of Qua Iboe River system, Niger-Delta, Nigeria. Elixir Pollution, 47, 9064-9073.

11. Andem, A. B., Udofia, U. U., Okorafor, K. A., \& George, U. U. (2013). Bioaccumulation of some heavy metals and total hydrocarbon (THC) in the tissues of periwinkle (Tympanotonus fuscatus Var radula) in the Intertidal Regions of Qua Iboe River Basin, Ibeno, Akwa Ibom State, Nigeria. Greener Journal of Biological Sciences, 3(7), $253-259$.

12. Bone, Q., \& Marshall, N. B. (1982). Biology of fishes. Blackie and Son Ltd, 253.

13. MacArthur, R. H., \& Wilson, E. O. (1967). The theory of Island biogeography. Princeton University Press, Princeton, New Jersey.

14. Ekpo, I. E., Udo, M. T., \& Oden, E. (2014). Trophic spectra and relationship of fish species assemblages in Qua Iboe River, Niger Delta, Nigeria. Nigerian Journal of Fisheries, 11(1\&2), 684-697.

15. Tahal Consultants (Nigeria) Ltd. (1979). Qua Iboe River Basin Prefeasibility Study. Cross River Basin Development Authority, Nigeria. 2, Annex II: A - 1 - 14 .

16. Pauly, D. (1980). On the inter-relationship between natural mortality, growth parameters and mean environmental temperature in 175 fish stocks. Journal of Cons. Int. Expl. Mer., 39(2), 175-179.

17. Pauly, D. (1990). Length-converted catch curves and the seasonal growth of fishes. Fishbyte, 8(3), 33-38.

18. Pauly, D., \& Munro, J. L. (1983). Once more on growth comparison in fish and invertebrates. Fishbyte, 2(1), 21-34.

19. Lagler, K. F., Bardach, J. E., Miller, R. R., and Assino, D. R. M. (1977). Ichthyology. $2^{\text {nd }}$ Ed. Wileyand Sons, New York, 506.

20. Wilkinson, D. R., \& Jones, J. W. (1977). The fecundity of dace, Leuciscus leuciscus (L.) in Emral Brook, Clwyd, North Wales. Freshwater Biology, 7, 135-145.

21. Lowenberg, U., \& Keunzel, T. (1992). Investigation on the hydrology of the lower Cross River, Nigeria. Anim. Res. Dev, 35, 72-75.

22. Moses, B. S. (1988). Growth, mortality and potential yield of bonga, Ethmalosa fimbriata (Bowdich 1825) of Nigerian inshore waters. Fisheries Research, 6, 233-247.

23. Djama, T. H., Gabche, C., \& Youmbi-Tienctheu, J. (1989). Comparison of the growth of West African stock of Sardinella maderensis with emphasis on Cameroon. Fishbyte J. Fish. Biol., 5, 205-225.

24. Per, S., Ursin, E., \& Venema, S. C. (1989). Introduction to tropical fish assessment: Part 1-Manual.

25. Gulland, J. A. (1971). Fish Resources of the Ocean Fishing New Books.

26. Ikusemiju, K., Oki, A. A., \& Graham, D. M. (1983). On the biology of the estuarine population of the clupeid Pellonula afzeliusi (Johnnels) in Lagos Lagoon, Nigeria. Hydrobiologia, 102, 55-59.

27. Marcus, O., \& Ikusemiju, K. (1984). Some aspects of reproductive biology of the clupeid Ilisha africana (Bloch) off the Lagos Coast, Nigeria. J. Fish Biol., 25: 679-689.

28. Stokholm, H., \& Isebor, C. (1993). The fishery of Ilisha africana in the coastal waters of Republic of Benin and Lagos State, Nigeria.

29. Roff, D. A. (1986). Predicting body size with life-history models. Bioscience, 36(5), 316-323.

30. Keanleyside, M. (1983). Mate desertion in relation to adult sex ratio in the biparental cichlid fish, Heterotilapia multispinosa. Anim. Behaviour, 31, 683-688.

31. Kapetsky, J. M. (1977). Some ecological aspect of the shallow lakes of the Magdalena flood plain, Columbia. Paper presented to the intertropical symposium on stability and diversity in tropical communities, Panama, March, 11.

32. King, R. P. (1991). Some aspects of the reproductive strategy of Ilisha africana (Bloch, 1795)(Teleostei, Clupeidae) in Qua Iboe estuary, Nigeria. Cybium (Paris), 15(3), 239-257.

33. Weasel, G. F., Hanzel, D. A., \& Newell, R. L. (1973). The Pygamy while fish, Prosopium coulteri in West Monatana. Fishery Bulletin, 70(2), 587-596.

34. McNaughton, S. J., \& Wolf, L. L. (1979). General Ecology. Holt, Rinehart and Winston, 702.

35. O'Hara, K., \& Penczak, T. (1987). Production of the three-spined stickleback, Gasterosteus aculeatus L., in the River Weaver, England. Freshwater Biology, 18, 252-360. 